\title{
Fibrin-Dependent Platelet Procoagulant Activity Requires GPIb Receptors and von Willebrand Factor
}

\author{
By S. Béguin, R. Kumar, I. Keularts, U. Seligsohn, B.S. Coller, and H.C. Hemker
}

\begin{abstract}
Thrombin generation in platelet-rich plasma (PRP) involves complex interactions between platelets and coagulation proteins. We previously reported that the addition of fibrin to PRP enhances tissue-factor initiated thrombin generation by $\approx 40 \%$, and the current studies were designed to assess the mechanism(s) underlying thrombin generation in the absence and presence of fibrin. Blocking platelet GPIlb/ Illa + $\alpha$ VB3 receptors with a monoclonal antibody (MoAb) inhibited basal thrombin generation, but did not affect the enhancement produced by fibrin. In contrast, blocking GPIb with any of three different MoAbs had no effect on basal thrombin generation, but essentially eliminated fibrin enhancement of thrombin generation. When thrombin generation was tested in PRP deficient in von Willebrand factor (vWF), both basal and fibrin-enhanced thrombin generation were markedly reduced, and the addition of factor VIII did
\end{abstract}

$\mathbf{T}$ HE FORMATION OF AN arterial thrombus involves platelet deposition, activation of coagulation, and fibrin formation. There is abundant evidence that platelets can facilitate thrombin generation by a number of different mechanisms. ${ }^{1}$ We recently showed that in a fibrin-free system consisting of gel-filtered platelets and defibrinated plasma, inhibition of platelet GPIIb/IIIa $+\alpha v \beta 3$ receptors with monoclonal antibody $(\mathrm{MoAb}), 7 \mathrm{E} 3$, inhibits ex vivo thrombin generation induced by tissue factor by $\approx 47 \%^{1}$; similar inhibition by $7 \mathrm{E} 3$ was observed using platelet-rich plasma (PRP), ${ }^{1}$ a system in which fibrin formation occurs late in the course of the experiment. The inhibition of thrombin generation correlated with decreased platelet microparticle formation, offering a possible mechanistic explanation, as platelet microparticle formation results in loss of the normal asymmetry of platelet membrane phospholipids leading to surface exposure of negatively-charged phospholipids, which are highly active in supporting thrombin generation. ${ }^{2-4}$

In separate experiments, we found that fibrin itself can enhance platelet membrane procoagulant activity (PMPA) when

From the Department of Biochemistry, Cardiovascular Research Institute Maastricht (CARIM) and Medical Faculty University of Maastricht, Maastricht, The Netherlands; the Department of Hematology, Sheba Medical Center, Tel Hashomer and Sackler Faculty of Medicine, Tel-Aviv University, Tel-Aviv, Israel; and the Department of Medicine, Mount Sinai School of Medicine, New York, NY.

Submitted May 26, 1998; accepted September 8, 1998.

Supported in part by Program Grant No. 900-526-192 from the Dutch Organization for Scientific Research (N.W.O.) and in part by Grants No. 19278 and 54469 from the National Heart, Lung and Blood Institute, Bethesda, MD.

Address reprint requests to B. S. Coller, MD, Box 1118, Mount Sinai School of Medicine, One Gustave L. Levy Place, New York, NY 10029; e-mail: bcoller@smtplink.mssm.edu.

The publication costs of this article were defrayed in part by page charge payment. This article must therefore be hereby marked "advertisement" in accordance with 18 U.S.C. section 1734 solely to indicate this fact.

(1) 1999 by The American Society of Hematology.

0006-4971/99/9302-0004\$3.00/0 not normalize thrombin generation. Botrocetin, which induces the binding of VWF to GPIb, enhanced thrombin generation. In all studies, the ability of PRP to support thrombin generation correlated with the production of platelet-derived microparticles and serum platelet-derived procoagulant activity. Thus, two separate mechanisms, both of which depend on VWF, appear to contribute to plateletderived procoagulant activity: one is independent of fibrin and relies primarily on GPIIb/ Illa, but with a minor contribution from $\alpha \mathrm{V} \beta 3$; and the other is fibrin-dependent and relies on GPIb. These data may have implications for understanding the mechanisms of the abnormalities in serum prothrombin times reported in Bemard-Soulier syndrome, hemormage in von Willebrand disease (VWD), and the increased risk of thrombosis associated with elevated vWF levels. (1) 1999 by The American Society of Hematology.

added to PRP, even when fibrin is formed in a way that it does not contain thrombin. ${ }^{5,6}$ Thus, the explosive generation of thrombin that occurs in recalcified PRP after a lag-phase (see eg, Fig 1) is probably the result of a composite resonance loop in which (1) the generation of small amounts of thrombin converts fibrinogen to fibrin, (2) both thrombin and fibrin activate platelet to produce PMPA, and (3) the enhanced PMPA facilitates the generation of more thrombin and fibrin. Thus, fibrin appears to play an active role in amplifying thrombin generation and further fibrin formation.

The current studies were designed to assess the relative contributions of thrombin and fibrin to PMPA production under different experimental conditions and to identify the platelet membrane receptors and adhesive ligands that are responsible for the fibrin-platelet interactions that result in enhanced thrombin generation. Thus, we investigated the roles of GPIIb/ IIIa, $\alpha v \beta 3$, GPIb, GPIa/IIa ( $\alpha 2 \beta 1)$, and von Willebrand factor (vWF).

\section{MATERIALS AND METHODS}

Reagents. The chromogenic substrate used for measuring thrombin was S2238: H-D-Phe-Pip-Arg-pNA.2HCl. Buffer A: 20 mmol/L HEPES, $150 \mathrm{mmol} / \mathrm{L} \mathrm{NaCl}, 0.5 \mathrm{~g} / \mathrm{L}$ bovine serum albumin (BSA; Lot A-7030, Sigma, St Louis, MO), pH 7.35. Buffer B: same as buffer A with 20 $\mathrm{mmol} / \mathrm{L}$ EDTA, $\mathrm{pH}=7.9$. Antibody binding buffer (FACScan): 10 $\mathrm{mmol} / \mathrm{L} \mathrm{HEPES}, 0.15 \mathrm{~mol} / \mathrm{L} \mathrm{NaCl}, 5 \mathrm{mmol} / \mathrm{L} \mathrm{KCl}, 1 \mathrm{mmol} / \mathrm{L} \mathrm{MgCl}_{2}$, $2.5 \mathrm{mmol} / \mathrm{L} \mathrm{CaCl}_{2}$ (pH 7.4). Synthetic d-arginyl-L-glycyl-L-aspartyl-Ltryptophan (d-RGDW) (Mr 530) was obtained from Rhone-Poulenc Rorer Antony (Paris, France). Botrocetin was from Kordia (Leiden, The Netherlands). Phospholipid vesicles were prepared from a mixture of $20 \%$ brain phosphatidyl serine (PS) and $80 \%$ egg phosphatidyl choline (PC) sonicated into a buffer containing $50 \mathrm{mmol} / \mathrm{L}$ Tris $\mathrm{HCl}(\mathrm{pH} 7.35$ ) and $100 \mathrm{mmol} / \mathrm{L} \mathrm{NaCl}$. All other reagents were of the highest grade commercially available.

Proteins and antibodies. Bovine factors $\mathrm{Xa}$ and $\mathrm{Va}$ and human prothrombin were kindly provided by Dr R Wagenvoord (Maastricht University, Maastricht, The Netherlands). Recombinant tissue factor was obtained from Dade (Düdingen, Switzerland). Agihal, purified fraction of Agkistrodon halys halys snake venom, which splits fibrinopeptide A from fibrinogen, was obtained from Prof L. Yukelson (Tashent, Uzbekistan). Staphylocoagulase was prepared as described. ${ }^{7}$ Recombinant factor VIII (rFVIII; Recombinate, Baxter, Deerfield, IL) 
contains only traces of vWF ( $<2$ ng per unit of factor VIII). Fluorescein isothiocyanate (FITC)-labeled annexin V (Apoptest, Oregon Green) was from NeXius Research BV (Hoeven, The Netherlands).

Murine MoAbs, 7E3 (anti-GPIIb/IIIa $+\alpha v \beta 3)^{8}$, 6D1 (anti-GPIb $\alpha$ ), ${ }^{9}$ and $6 \mathrm{~F} 1$ (anti-GPIa/IIa) ${ }^{10}$ have been previously described in detail. MoAb CD42b (anti-GPIb) was from Immuntech (Marseille, France) and MoAb AP-1 (anti-GPIb) was a kind gift of Dr Thomas Kunicki (Scripps Institute, La Jolla, CA). R-phycoerythrin-conjugated MoAbs to human GPIIb/IIIa (5B12) and GPIb (AN51) were obtained from Dako (Glostrup, Denmark). An affinity-purified polyclonal antibody to vWF was obtained from the Central Laboratory of the Red Cross (CLB) in Amsterdam, The Netherlands.

Preparation of plasma. PRP was obtained by centrifuging fresh citrated blood ( 9 parts of blood to one part of $0.13 \mathrm{~mol} / \mathrm{L}$ trisodium citrate) at $250 \mathrm{~g}, 15^{\circ} \mathrm{C}$ for 10 minutes. The platelet count was adjusted to $3 \times 10^{8} / \mathrm{mL}$ using autologous platelet-poor plasma (PPP).

The study included four patients with Glanzmann thrombasthenia of Iraqi-Jewish descent (GPIIIa defect leading to loss of both GPIIb/IIIa and $\alpha v \beta 3$ ) and three of Arab descent (GPIIb defect leading to loss of GPIIb/IIIa, but normal or increased $\alpha v \beta 3$ ) residing in Israel. ${ }^{11}$ By courtesy of Dr Karly Hamulyak (Academic Hospital, Maastricht), blood was obtained from one patient with Glanzmann thrombasthenia, and one with von Willebrand disease (vWD) type IIa. By courtesy of Dr J. Eikelboom $^{12}$ (Academic Hospital Leiden), blood was obtained from a patient with type III vWD (described in Weiss et $\mathrm{a}^{13}$ ).

Preparation of clots. Fibrin I clots (noncross-linked, des AA fibrin) were prepared as previously described using the snake venom protease Agihal. Addition of clots to PPP did not cause coagulation within 2 hours and did not influence either the clotting time or thrombin generation in recalcified PPP. Three clots were added to PRP in the thrombin generation experiments, representing $\approx 3$ times the potential fibrin content of the PRP.

Measurement of thrombin generation. Thrombin generation in plasma was performed as described previously. ${ }^{14,15}$ In short, for thrombin generation in PPP, $20 \mu \mathrm{L}$ of a kaolin suspension and $20 \mu \mathrm{L}$ of Buffer A were added to $240 \mu \mathrm{L}$ of PPP. At 4 minutes, $20 \mu \mathrm{L}$ of PS/PC $(20 \mu \mathrm{mol} / \mathrm{L})$ was added and at 5 minutes, coagulation was triggered by adding $60 \mu \mathrm{L}$ of $0.1 \mathrm{~mol} / \mathrm{L} \mathrm{CaCl} 2$. For thrombin generation in PRP, 240 $\mu \mathrm{L}$ of PRP was incubated with $60 \mu \mathrm{L}$ of Buffer A or buffer containing the antibody or other additions to be tested for 10 minutes at $37^{\circ} \mathrm{C}$. Fibrin clots were added just before coagulation was initiated by adding $60 \mu \mathrm{L}$ of $0.1 \mathrm{~mol} / \mathrm{L} \mathrm{CaCl}_{2}, 1.8 \mathrm{fmol} / \mathrm{L}$ tissue factor.

One minute after initiating coagulation, $10 \mu \mathrm{L}$-samples of the reaction mixture were taken at 1-minute intervals and added to prewarmed $\left(37^{\circ} \mathrm{C}\right)$ cuvettes containing $490 \mu \mathrm{L}$ of $200 \mu \mathrm{mol} / \mathrm{L} \mathrm{S} 2238$ in buffer B. The reaction was stopped after 2 minutes by adding $300 \mu \mathrm{L}$ of $1 \mathrm{~mol} / \mathrm{L}$ citric acid, and the optical density (OD) was measured at 405 $\mathrm{nm}$. Thrombin amidolytic activity was calculated by comparing the $\mathrm{OD} /$ minute value of the test sample to a thrombin standard calibration curve. Free thrombin was calculated from thrombin amidolytic activity using our previously described computer program that takes into account the contributions of free thrombin and $\alpha 2$-macroglobulinbound thrombin. ${ }^{15}$

The lag time of thrombin formation is defined as the time from addition of the triggering solution to the time at which the thrombin concentration increases above $10 \mathrm{nmol} / \mathrm{L}$ and the endogenous thrombin potential (ETP) is defined as the area under the thrombin generation curve. ${ }^{16,17}$ In normal PRP, the ETP is $411 \pm 13 \mathrm{nmol} / \mathrm{L} \times \min$ (mean \pm standard error of mean [SEM], $\mathrm{n}=28$ ).

Measurement of platelet-derived procoagulant activity and microparticles in serum. The platelet-membrane derived procoagulant phospholipid activity (PMPA) was determined by diluting serum prepared from PRP after thrombin generation experiments 3:20 in buffer A and adding a $50-\mu \mathrm{L}$ aliquot of the diluted serum to $100 \mu \mathrm{L}$ of an assay mixture containing $0.45 \mathrm{nmol} / \mathrm{L}$ factor $\mathrm{Xa}, 10.5 \mathrm{nmol} / \mathrm{L}$ factor $\mathrm{Va}, 3 \mu \mathrm{mol} / \mathrm{L}$ prothrombin and $12 \mathrm{mmol} / \mathrm{L} \mathrm{Ca}^{2+}$ in buffer A. At 4 minutes, a $10 \mu \mathrm{L}$ subsample was added to cuvettes containing $465 \mu \mathrm{L}$ of buffer B. Thrombin concentrations were then assayed with $\mathrm{S} 2238$ by determining the change in absorbance over time. Normal serum gives values of $115 \pm 5.5 \mathrm{nmol} / \mathrm{L} /$ minute (mean $\pm \mathrm{SEM}, \mathrm{n}=22$ ), equivalent to the effect of $300 \mathrm{nmol} / \mathrm{L}$ PS/PC (20\%/80\%) vesicles. Normal PPP or the serum left after a thrombin generation experiment in PPP gives values $<12 \mathrm{nmol} / \mathrm{L} /$ minute.

To detect platelet-derived microparticles, $15 \mu \mathrm{L}$ of serum was incubated with R-phytoerythrin-conjugated mouse MoAbs against GPIIb/IIIa or GPIb. To assess the presence of anionic phospholipids on the microparticles, $250 \mu \mathrm{L}$ of $2 \mu \mathrm{g} / \mathrm{mL}$ FITC-labeled annexin V was added. The analysis was performed in a flow cytometer (EPICS XL-MCL; Becton Dickinson \& Co, San Jose, CA). A total of 10,000 events was recorded and the data were analyzed using the CellQuest software program, version 1.2 (Becton Dickinson \& Co). There was a high correlation between annexin- $\mathrm{V}$-positive and platelet glycoproteinpositive particles, indicating that the particles that exposed PS were derived from platelets.

Measurement of residual prothrombin in serum. Residual prothrombin was assessed as previously described. ${ }^{7,15,18}$

\section{RESULTS}

The effects of adding fibrin clots to normal PRP and of blocking GPIIb/IIIa $+\alpha v \beta 3$, GPIb, and GPIa/IIa $(\alpha 2 \beta 1)$ receptors. Consistent with our earlier observations, adding fibrin clots to normal PRP enhanced the ETP by $\approx 42 \%$, peak thrombin generation by $\approx 64 \%$, platelet-derived microparticles (PDMP) by $\approx 44 \%$, and PMPA by $\approx 78 \% 5$ (Fig 1 and Table 1 ). It also decreased residual prothrombin by $\approx 50 \%$ (Table 1 ). Also consistent with our earlier observations, blockade of GPIIb/IIIa $+\alpha v \beta 3$ receptors by antibody 7E3 or the peptide d-RGDW (60 $\mu \mathrm{mol} / \mathrm{L}$ ) decreased ETP of PRP to $42 \%$ and $60 \%$ of normal, respectively ${ }^{1}$ (Fig 1 and Table 1). The other parameters of thrombin generation were affected in a manner consistent with the inhibitory effects of these agents on the ETP (Table 1). What was most remarkable, however, was the ability of fibrin clots to enhance thrombin generation in PRP in which GPIIb/IIIa +

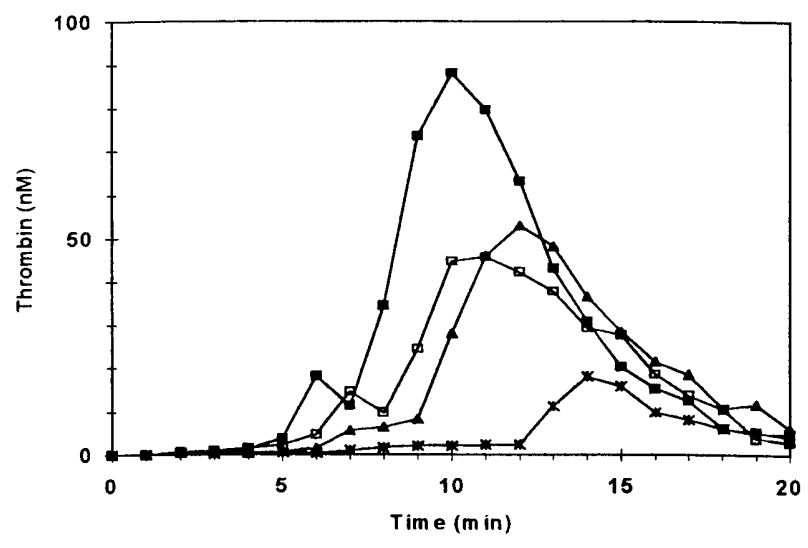

Fig 1. Effect of blocking GPIlb/ Illa $+\alpha V \beta 3$ receptors on thrombin generation in the absence and presence of fibrin clots. Thrombin generation was triggered at $t=0$ in PRP (adjusted to $3 \times 10^{8} / \mathrm{mL}$ ) by recalcification and addition of tissue factor. $(\square)$ Control; $(\square)$ three fibrin clots added at $\mathbf{t}=\mathbf{0}$; $(*)$ PRP preincubated with antibody 7E3

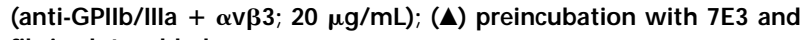
fibrin clots added. 
Table 1. Effect of GPIlb/ Illa $+\alpha$ V $\beta 3$, GPlb, and GPla/ lla Blockade on Thrombin Generation in PRP in the Presence and Absence of Fibrin Clots

\begin{tabular}{|c|c|c|c|c|c|c|c|}
\hline Conditions & $\begin{array}{l}\text { Fibrin } \\
\text { Clots }\end{array}$ & No. & $\begin{array}{c}\text { ETP } \\
\%\end{array}$ & $\begin{array}{c}\text { Peak- } \\
\text { Thrombin } \\
\%\end{array}$ & $\begin{array}{c}\text { PDMP } \\
\%\end{array}$ & $\begin{array}{c}\text { PMPA } \\
\%\end{array}$ & $\begin{array}{c}\text { Residua } \\
\text { Factor II } \\
\%\end{array}$ \\
\hline \multirow{2}{*}{ Control } & - & 16 & 100 & 100 & 100 & 100 & $12 \pm 2$ \\
\hline & + & 16 & $142 \pm 4$ & $164 \pm 11$ & $144 \pm 7$ & $178 \pm 12$ & $6 \pm 1$ \\
\hline \multirow{2}{*}{$\begin{array}{l}\text { Anti-GPIIb/IIla }+\alpha v \beta 3 \\
\quad(7 E 3)\end{array}$} & - & 10 & $42 \pm 4$ & $41 \pm 4$ & $44 \pm 6$ & $42 \pm 3$ & $32 \pm 1$ \\
\hline & + & 10 & $92 \pm 6$ & $89 \pm 9$ & $91 \pm 6$ & $72 \pm 10$ & $20 \pm 2$ \\
\hline \multirow[t]{2}{*}{ d-RGDW (60 $\mu \mathrm{mol} / \mathrm{L})$} & - & 4 & 60 & 49 & 56 & 74 & 25 \\
\hline & + & 4 & 98 & 83 & 72 & 90 & 11 \\
\hline \multicolumn{8}{|l|}{ Anti-GPIb } \\
\hline \multirow[t]{2}{*}{$6 \mathrm{D} 1$} & - & 6 & $98 \pm 7$ & $95 \pm 8$ & $99 \pm 11$ & $97 \pm 11$ & $14 \pm 2$ \\
\hline & + & 6 & $85 \pm 9$ & $96 \pm 14$ & $92 \pm 14$ & $95 \pm 15$ & $12 \pm 3$ \\
\hline \multirow[t]{2}{*}{ AP-1 } & - & 3 & 101 & 94 & 100 & 104 & 13 \\
\hline & + & 3 & 97 & 97 & 95 & 98 & 14 \\
\hline \multirow[t]{2}{*}{$\mathrm{CD} 42 \mathrm{~b}$} & - & 3 & 103 & 98 & 98 & 95 & 12 \\
\hline & + & 3 & 93 & 95 & 104 & 87 & 14 \\
\hline \multirow{2}{*}{$\begin{array}{l}\text { Anti-GPIIb/IIIa + GPIb } \\
\text { (7E3 and 6D1) }\end{array}$} & - & 3 & 46 & 59 & 49 & 37 & 32 \\
\hline & + & 3 & 51 & 57 & 55 & 40 & 30 \\
\hline \multirow{2}{*}{$\begin{array}{l}\text { Anti-GPla/lla } \\
\qquad(6 \mathrm{~F} 1)\end{array}$} & - & 4 & 105 & 100 & 98 & 104 & 11 \\
\hline & + & 4 & 135 & 171 & 148 & 150 & 7 \\
\hline \multirow{2}{*}{$\begin{array}{l}\text { Anti-GPIIb/llla + la/lla } \\
\quad(7 E 3 \& 6 F 1)\end{array}$} & - & 3 & 58 & 55 & 49 & 47 & 26 \\
\hline & + & 3 & 90 & 89 & 101 & 73 & 19 \\
\hline \multirow{2}{*}{$\begin{array}{l}\text { Ionomycin }(10 \mu \mathrm{mol} / \mathrm{L}) \\
\text { (see legend) }\end{array}$} & - & 14 & $139 \pm 4$ & $145 \pm 9$ & $154 \pm 14$ & $147 \pm 9$ & $6 \pm 1$ \\
\hline & + & 14 & $136 \pm 4$ & $140 \pm 10$ & $144 \pm 16$ & $152 \pm 9$ & $6 \pm 1$ \\
\hline
\end{tabular}

The final concentration of each MoAb used was $20 \mu \mathrm{g} / \mathrm{mL}$. d-RGDW was used at $60 \mu \mathrm{mol} / \mathrm{L}$, ionomycin at $10 \mu \mathrm{mol} / \mathrm{L}$. None of the antibodies had a measurable effect on thrombin generation in the presence of ionomycin, so all values were pooled in this case. Values are expressed as mean \pm SEM and as a percentage of a normal control assayed concomitantly, except for the residual prothrombin content in the serum (last column), which is expressed as \% of the original prothrombin content of the plasma. No SEM is given if $n<5$; individual values were within $15 \%$ of the mean.

Abbreviations: ETP, endogenous thrombin potential; peak thrombin, highest thrombin concentration observed; PDMP, platelet derived, annexin V-positive microparticles; PMPA, platelet membrane-derived procoagulant phospholipid activity.

$\alpha \mathrm{v} \beta 3$ receptors had been blocked by 7E3 or d-RGDW (Fig 1 and Table 1).

Blocking the vWF binding domain of GPIb with antibody $6 \mathrm{D} 1 \mathrm{had}$ the mirror image effect of GPIIb/IIIa $+\alpha \mathrm{v} \beta 3$ blockade; thus, it had no effect on thrombin generation in the absence of added fibrin, but prevented the procoagulantenhancing effect of fibrin (Fig 2 and Table 1). Two other antibodies against GPIb (AP-1 and CD 426) gave similar results

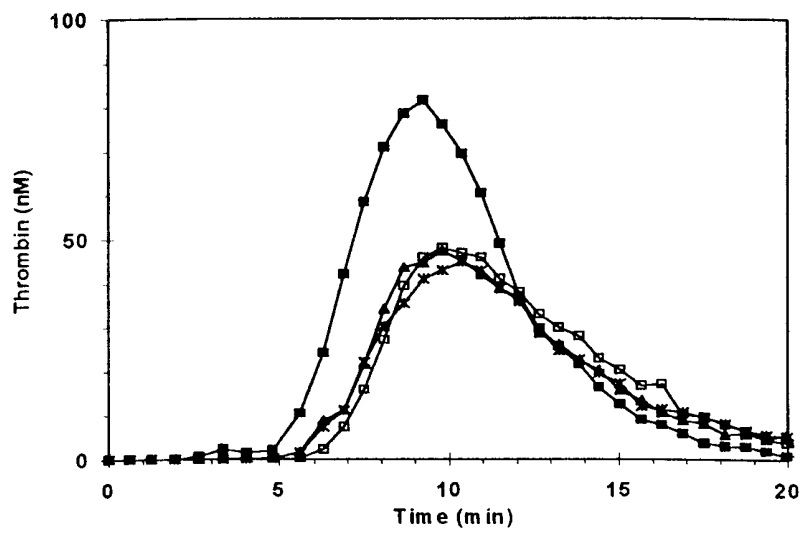

Fig 2. Effect of blocking GPIb receptors on fibrin-enhanced platelet procoagulant activity. Thrombin generation was measured as in Fig 1. ( $\square$ ) Control; ( $(\square)$ three fibrin clots added at $t=0$; (*) PRP preincubated with antibody $6 \mathrm{Dl}$ (anti-GPIb $\alpha, 20 \mu \mathrm{g} / \mathrm{mL}$ ); ( $(\Lambda)$ preincubation with $6 \mathrm{D} 1$ and fibrin clots added.
(Table 1). When antibodies 7E3 and 6D1 were used in combination, the results were additive, with both a reduction in thrombin generation and near elimination of the enhancement of thrombin generation by adding fibrin (Table 1). The MoAb $6 \mathrm{~F} 1$, which blocks GPIa/IIa, affected neither normal thrombin generation nor the enhanced thrombin generation in the presence of fibrin, and thus served as a control (Table 1). Ionomycintreated PRP supported thrombin generation to the same extent as did normal PRP with added fibrin (Table 1). None of the antibodies inhibited thrombin generation supported by ionomycin-treated platelets (data not shown).

Studies using PRP from patients with Glanzmann thrombasthenia. Because antibody 7E3 blocks both platelet GPIIb/IIIa and $\alpha v \beta 3$, we tried to assess the contributions of each of these receptors by comparing the results using PRP from different patients with Glanzmann thrombasthenia. Iraqi-Jewish patients have no detectable GPIIb/IIIa or $\alpha v \beta 3$, whereas Israeli-Arab patients have virtually no GPIIb/IIIa, but approximately twice the normal level of platelet $\alpha v \beta 3 .{ }^{11,19}$ In both patient groups, thrombin generation in PRP is decreased to about $60 \%$ of normal (Table 2). Antibody 7E3 decreased thrombin generation in PRP of two Arab patients tested (from 68\% to 59\% and from $35 \%$ to $25 \%$ ), but had virtually no effect on thrombin generation in the PRP of Iraqi-Jewish patients (from $71 \%$ to $70 \%$ and from $63 \%$ to $65 \%$ ) (Table 2). Addition of fibrin clots to the PRP of patients in either group resulted in increased thrombin generation (increases of $\approx 18 \%, 44 \%$, and $103 \%$ for Arab patients B, 
Table 2. Thrombin Generation in PRP of Normal and Glanzmann Thrombasthenia (GT) Patients

\begin{tabular}{|c|c|c|c|c|}
\hline Patient & Additions & $\begin{array}{c}\text { ETP } \\
\%\end{array}$ & $\begin{array}{c}\text { Peak } \\
\text { Thrombin } \\
\%\end{array}$ & $\begin{array}{c}\text { PMPA } \\
\%\end{array}$ \\
\hline Normal & None & 100 & 100 & 100 \\
\hline \multicolumn{5}{|l|}{ Arab } \\
\hline \multirow[t]{3}{*}{ A } & None & 68 & 59 & 49 \\
\hline & 7E3 & 59 & 42 & 36 \\
\hline & $7 \mathrm{E3}+$ clots & 76 & 69 & 74 \\
\hline \multirow[t]{4}{*}{ B } & None & 66 & 63 & 55 \\
\hline & Clots & 78 & 77 & 102 \\
\hline & $6 \mathrm{~F} 1$ & 69 & 61 & 58 \\
\hline & $6 \mathrm{~F} 1+$ clots & 77 & 89 & 93 \\
\hline \multirow[t]{2}{*}{$\mathrm{C}$} & None & 70 & 63 & 35 \\
\hline & Clots & 101 & 89 & 52 \\
\hline \multirow[t]{3}{*}{$D$} & None & 35 & 26 & 44 \\
\hline & Clots & 71 & 56 & 52 \\
\hline & 7E3 & 25 & 16 & 28 \\
\hline \multicolumn{5}{|c|}{ Iraqi-J ewish } \\
\hline \multirow[t]{2}{*}{ A } & None & 54 & 34 & 27 \\
\hline & Clots & 69 & 55 & 41 \\
\hline \multirow[t]{3}{*}{ B } & None & 71 & 63 & 48 \\
\hline & 7E3 & 70 & 58 & 45 \\
\hline & 7E3 + clots & 87 & 91 & 61 \\
\hline \multirow[t]{3}{*}{$\mathrm{C}$} & None & 63 & 45 & 36 \\
\hline & 7E3 & 65 & 41 & 42 \\
\hline & 7E3 + clots & 77 & 67 & 44 \\
\hline D & None & 65 & 47 & 57 \\
\hline
\end{tabular}

Values are expressed as a percentage of a normal control assayed concomitantly. Legend as in Table 1.

$\mathrm{C}$, and $\mathrm{D}$; and $\approx 28 \%$ for Iraqi-Jewish patient A), supporting the conclusions derived from the antibody studies, namely that the effect of fibrin does not require either GPIIb/IIIa or $\alpha \mathrm{v} \beta 3$ receptors.

Experiments with $v W F$. Because vWF has been reported to bind to fibrin and support an interaction with platelet $\mathrm{GPIb}^{20}$, we investigated the effect of vWF on thrombin generation. Decreasing vWF activity of normal PRP with a neutralizing antibody not only prevented the enhancement of thrombin generation produced by fibrin, but, unexpectedly it also diminished baseline thrombin generation (Fig 3). In contrast, thrombin generation in PPP was unaffected by vWF neutralization (Fig 3, inset), indicating that there was sufficient factor VIII coagulant activity in the antibody-treated plasma to support thrombin generation. Addition of ionomycin (Fig 3) or a frozen and thawed platelet lysate (not shown) restored normal thrombin generation, indicating that the defect caused by vWF could be overcome by activated platelets.

Additional experiments were performed with PRP of patients with mild and severe vWD. Thrombin generation in the PRP of a patient with mild vWD (type IIa, $\approx 30 \%$ factor VIII and $4 \%$ vWF antigen) was $\approx 60 \%$ of normal. Adding anti-vWF antibody reduced thrombin generation to $\approx 12 \%$ of normal (Fig 4 ). The patient's factor VIII coagulant activity was sufficient to support thrombin generation as demonstrated by normal thrombin generation using the patient's PPP (Fig 4, inset), with or without the addition of the anti-vWF antibody.

Thrombin generation in PRP from a patient with type III, severe vWD $(<1 \%$ of vWF antigen and factor VIII) was more

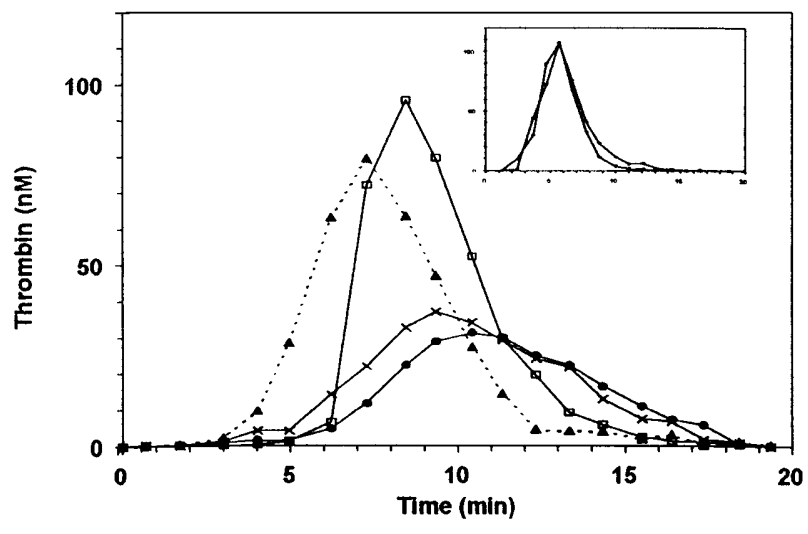

Fig 3. Effect on thrombin generation of reducing vWF activity in plasma. ( $\square$ ) Control (normal PRP with $10 \mu \mathrm{g} / \mathrm{mL}$ rabbit IgG); (๑) PRP preincubated with vWF antibody $(10 \mu \mathrm{g} / \mathrm{mL}) ;(X)$ PRP preincubated with anti-vWF $(10 \mu \mathrm{g} / \mathrm{mL})$, three fibrin clots added at $t=90 \mathrm{~s} ;(\Lambda)$ preincubated with vWF antibody and $10 \mu \mathrm{mol} / L$ ionomycin added at $\mathbf{t}=10 \mathrm{~s}$. (Inset) Thrombin generation in PPP. The reaction was triggered with PS/PC and $\mathrm{Ca}^{2+}$. ( $\square$ ) Control PPP with $10 \mu \mathrm{g} / \mathrm{mL}$ rabbit IgG; (Ө) PPP preincubated with anti-vWF (10 $\mu \mathrm{g} / \mathrm{mL})$.

severely diminished than in the PRP of a patient with mild vWD (Fig 5, upper frame). Addition of sufficient rFVIII to increase the factor VIII coagulant activity to $100 \%$ normalized thrombin generation in PPP (Fig 5, lower frame) yet only partially restored thrombin generation in PRP to $40 \%$ of normal (Fig 5, upper frame). The addition of $2.5 \%$ of normal rFVIII was without effect on thrombin generation in PRP, but the addition of $2.5 \%$ of normal PPP, which provides both vWF and essentially the same amount of factor VIII, restored thrombin generation (Fig 6). Adding ionomycin or either normal or patient platelet lysate (not shown) restored thrombin generation, indicating that procoagulant phospholipids were indeed ratelimiting. To further assess whether the interaction of vWF and GPIb enhanced thrombin generation, we added botrocetin to PRP and found that it did, indeed, increase thrombin generation

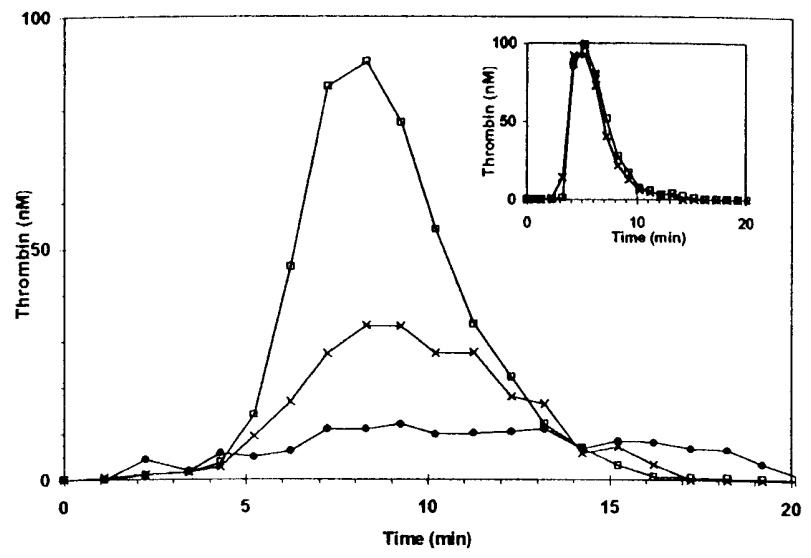

Fig 4. Thrombin generation in PRP of a patient with mild type lla vWF deficiency. The patient's plasma contained $30 \%$ factor $V I I I$ and $\approx$ 4\% of vWF antigen. ( $\square$ ) Control PRP (with $10 \mu \mathrm{g} / \mathrm{mL}$ rabbit lgG); $X$, patient's PRP (rabbit IgG added); (O) patient's PRP preincubated with anti-vWF antibody (10 $\mu \mathrm{g} / \mathrm{mL})$. Inset: thrombin generation in PPP. ( $\square$ ) Normal control; (X) patient. 

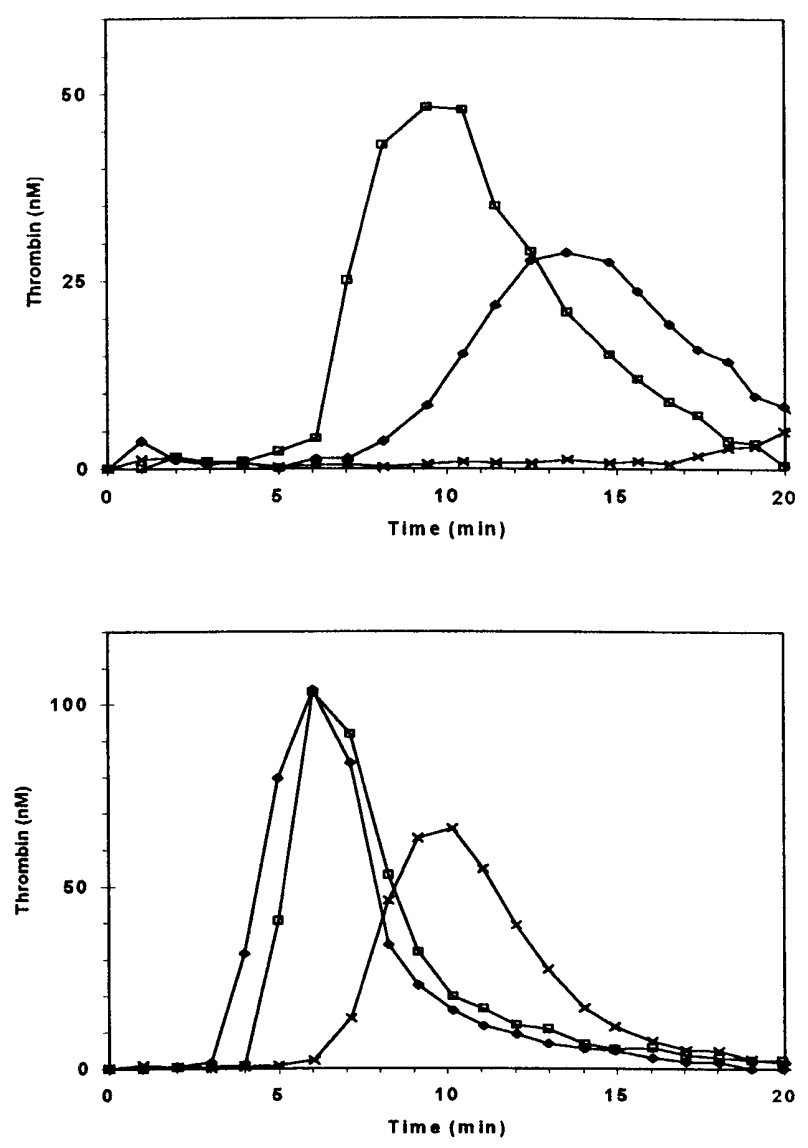

Fig 5. Thrombin generation in plasma of patient with type III severe vWD. The patient has less than $1 \%$ of factor VIII and VWF antigen and ristocetin cofactor activity. (Upper frame) ( $\square$ ) Normal PRP; (X) patient's PRP; $(\diamond)$ patient's PRP with $100 \%$ recombinant factor VIII added. (Lower frame) Thrombin generation in intrinsically triggered nondefibrinated PPP. ( $\square$ ) Normal PPP; (X) patient's PPP; ( $)$ patient's PPP with $100 \%$ recombinant FVIII added.

(Fig 7). Ristocetin could not be tested because in control experiments it inhibited thrombin generation in PPP.

\section{DISCUSSION}

We previously observed two different phenomena related to platelets and thrombin generation: (1) in a fibrin-free system or in a system in which fibrin is generated late in the reaction, blockade of GPIIb/IIIa and to a lesser extent $\alpha v \beta 3$ decreases thrombin generation, and (2) adding fibrin to PRP enhances thrombin generation. The present studies were designed to obtain data on the receptors, ligand, and mechanisms responsible for these phenomena. Despite the ability of GPIIb/IIIa to bind fibrinogen, polymerizing fibrin, and clotted fibrin under static or flow conditions, ${ }^{21-27}$ our current data indicate that the enhancing effect of fibrin on thrombin generation cannot be attributed to a GPIIb/IIIa-mediated mechanism because fibrin retains its stimulating effect in the presence of a GPIIb/IIIa + $\alpha v \beta 3$ blocking antibody or peptide, as well as when added to the PRP of Glanzmann patients.

We next studied the interaction between GPIb and vWF because platelets have been shown to bind to fibrin through the

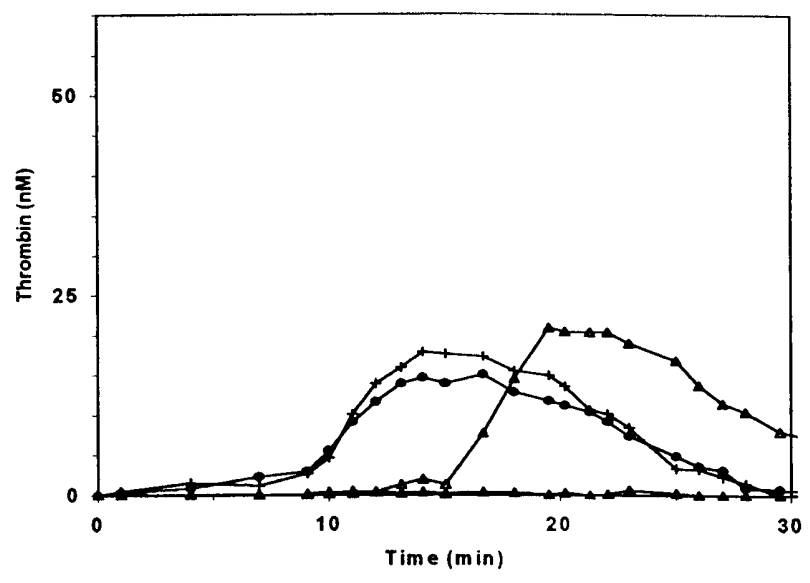

Fig 6. Thrombin generation in PRP of a patient with severe (type III) deficiency of vWF. $(\Delta)$ patient's PRP with $2.5 \%$ recombinant FVIII added; $(\triangle$ ) patient's PRP with $2.5 \%$ normal PPP added; (+) patient's PRP with $2.5 \%$ nomal PPP and with a frozen and thawed suspension of normal platelets added at $t=90 \mathrm{~s}$; (O) patient's PRP with $2.5 \%$ nomal PPP and with a frozen and thawed suspension of the patient's platelets. The final concentration of platelet material was equivalent to $2 \times 10^{7}$ platelets $/ \mathrm{mL}$.

interaction between fibrin-bound $\mathrm{vWF}$ and platelet GPIb. ${ }^{20}$ Although anti-GPIb MoAbs had no effect on thrombin generation in the absence of added fibrin clots, they essentially abolished the enhancing effect of the added fibrin. Thus, the fibrin effect seems to be mediated via GPIb. This observation provides a possible explanation for the abnormal prothrombin consumption previously reported in patients with BernardSoulier syndrome, whose platelets lack GPIb ${ }^{28-32}$ and the abnormal prothrombin consumption that we previously reported when antibody $6 \mathrm{D} 1$ was added to normal blood. ${ }^{9}$

In view of the important role of GPIb in the fibrin-dependent enhancement of thrombin generation in PRP, it is perhaps surprising that in normal, recalcified PRP, thrombin generation initiated by tissue factor is minimally inhibited by blocking GPIb. The most likely explanation is that in these experiments, fibrin begins to form late in the process, at the very beginning of the thrombin burst, and thus there is insufficient time for it to affect the process. When fibrin in the form of preformed clots is

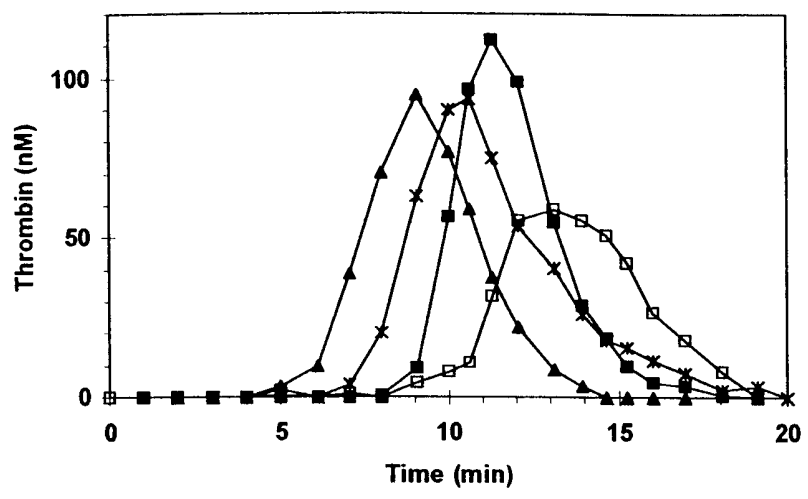

Fig 7. Effect of botrocetin on thrombin generation in PRP. ( $\square$ ) Normal PRP; (口) $5 \mu \mathrm{g} / \mathrm{mL}$ botrocetin added; (X) $25 \mu \mathrm{g} / \mathrm{mL}$; (A) 50 $\mu \mathbf{g} / \mathbf{m L}$. 
added before the thrombin burst occurs, it enhances thrombin generation and shortens the lag-phase in a GPIb-dependent mechanism. Taken together, our previous and current data indicate that these are two different pathways for augmenting platelet coagulant activity: (1) a GPIIb/IIIa- and perhaps $\alpha \mathrm{v} \beta 3$ dependent pathway that operates independently of fibrin, and (2) a fibrin-and GPIb-dependent pathway. Of note, based on data using neutralizing antibody to vWF and plasmas of patients with vWD, as well as our data using botrocetin, both pathways appear to depend on vWF, suggesting that vWF binding to GPIIb/IIIa (and perhaps $\alpha v \beta 3$ ) is important in the development of platelet coagulant activity.

The generation of PMPA and platelet-derived microparticles in serum and the consumption of prothrombin followed the same pattern of inhibition as did thrombin generation. This suggests that microparticle formation is responsible for the PMPA and that GPIIb/IIIa (and perhaps $\alpha v \beta 3$ ), GPIb, and vWF are all required for maximal microparticle formation in a fibrin-containing system. The ability of ionomycin-treated platelets and platelet lysates to overcome the abnormalities produced by the antibodies further suggests that the defects result in decreased microparticle formation.

From our results it appears that the fibrin in a clot or thrombus is not merely an inert, mechanical component. ${ }^{33}$ It also is clear that vWF, apart from its established function in platelet adherence and as a carrier of factor VIII, may also play an important role in the generation of thrombin through its effect on the generation of platelet microparticles and platelet coagulant activity. Because it has been proposed that the thrombosis associated with heparin-induced thrombocytopenia is linked to platelet microparticle formation, ${ }^{34,35}$ it is interesting to speculate that variations in vWF levels may account for the interindividual differences in thrombotic risk. Recently, platelet microparticles were found to support transcellular metabolism of eicosanoids, ${ }^{36}$ leading to activation of platelets and endothelial cells, as well as modulation of monocyte-endothelial interactions, ${ }^{37}$ and so it is possible that the mechanisms we are studying have implications for these phenomena as well. Finally, our observations have potential implications for understanding better the pathophysiology of the bleeding in vWD, as well as the association between elevated plasma vWF activity and acute myocardial infarction, ${ }^{38,39}$ as well as death after stroke. ${ }^{40}$

\section{ACKNOWLEDGMENT}

We are grateful to the patients who volunteered to give their blood and to their doctors, Dr Karly Hamulyak and Dr J. Eikenboom, for arranging the opportunity to study their plasma. Dr Ariella Zivelin has been a great support in the experiments with the PRP from the Iraqi-Jewish and Arab Glanzmann patients. Our thanks are due to Dr J.A. van Mourik for providing us the vWF antibodies. We also thank Dr J. Heemskerk for performing the $\mathrm{Ca}^{2+}$-influx experiments and $\mathrm{Dr} \mathrm{Hu}$ Kai for his method of measurement of microparticle procoagulant activity.

\section{REFERENCES}

1. Reverter JC, Beguin S, Kessels H, Kumar R, Hemker HC, Coller BS: Inhibition of platelet-mediated, tissue factor-induced, thrombin generation by the mouse/human chimeric 7E3 anibody: Potential implications for the effect of c7E3 Fab treatment on acute thrombosis and "clinical restenosis". J Clin Invest 98:863, 1996
2. Schroit AJ, Zwaal RF: Transbilayer movement of phospholipids in red cell and platelet membranes. Biochim Biophys Acta 1071:313, 1991

3. Basse F, Stout JG, Sims PJ, Wiedmer T: Isolation of an erythrocyte membrane protein that mediates $\mathrm{Ca} 2+$-dependent transbilayer movement of phospholipid. J Biol Chem 271:17205, 1996

4. Zhou Q, Zhao J, Stout JG, Luhm RA, Wiedmer T, Sims PJ: Molecular cloning of human plasma membrane phospholipid scramblase. A protein mediating transbilayer movement of plasma membrane phospholipids. J Biol Chem 272:18240, 1997

5. Kumar R, Béguin S, Hemker HC: The effect of fibrin clots and clot-bound thrombin on the development of platelet procoagulant activity. Thromb Haemost 74:962, 1995

6. Béguin S, Kumar R: Thrombin, fibrin and platelets: A resonance loop in which von Willebrand factor is a necessary link [published erratum, 78:973, 1997]. Thromb Haemost 78:590, 1997

7. Hendrix H, Lindhout $T$, Mertens $K$, Engels W, Hemker HC: Activation of human prothrombin by stoichiometric levels of staphylocoagulase. J Biol Chem 258:3637, 1983

8. Coller BS: A new murine monoclonal antibody reports an activation-dependent change in the conformation and/or microenvironment of the platelet GPIIb/IIIa complex. J Clin Invest 76:101, 1985

9. Coller BS, Peerschke EI, Scudder LE, Sullivan CA: Studies with a murine monoclonal antibody that abolishes ristocetin-induced binding of von Willebrand factor to platelets: Additional evidence in support of GPIb as a platelet receptor for von Willebrand factor. Blood 61:99, 1983

10. Coller BS, Beer JH, Scudder LE, Steinberg MH: Collagenplatelet interactions: Evidence for a direct interaction of collagen with platelet GPIa/IIa and an indirect interaction with platelet GPIIb/IIa mediated by adhesive proteins. Blood 74:182, 1989

11. Newman PJ, Seligsohn U, Lyman S, Coller BS: The molecular genetic basis of Glanzmann thrombasthenia in the Iraqi-Jewish and Arab populations in Israel. Proc Natl Acad Sci USA 88:3160, 1991

12. Eikenboom JC, Ploos vAH, Reitsma PH, Briet E: Mutations in severe, type III von Willebrand's disease in the Dutch population: Candidate missense and nonsense mutations associated with reduced levels of von Willebrand factor messenger RNA. Thromb Haemost 68:448, 1992

13. Weiss HJ, Hawiger J, Ruggeri ZM, Turitto VT, Thiagarajan P, Hofmann T: Fibrinogen-independent platelet adhesion and thrombus formation on subendothelium mediated by glycoprotein IIb-IIIa complex at high shear rates. J Clin Invest 83:288, 1989

14. Béguin S, Lindhout T, Hemker HC: The effect of trace amounts of tissue factor on thrombin generation in platelet rich plasma, its inhibition by heparin. Thromb Haemost 61:25, 1989

15. Hemker HC, Willems GM, Béguin S: A computer assisted method to obtain the prothrombin activation velocity in whole plasma independent of thrombin decay processes. Thromb Haemost 56:9, 1986

16. Hemker HC, Wielders S, Béguin S: The thrombin potential, a parameter to assess the effect of antithrombotic drugs on thrombin generation, in Bounameaux $\mathrm{H}$, Samama M, ten Cate JW (eds): Fraxiparin. Schattaurer, 1990, p 89

17. Hemker HC: Thrombin generation, an essential step in haemostasis and thrombosis, in Forbes CD, Thomas DP, Tuddenham EGD (eds): Haemostasis and Thrombosis. London, UK, Churchill Livingstone, 1993, p 477

18. Kawabata S, Morita T, Iwanaga S, Igarashi H: Staphylocoagulasebinding region in human prothrombin. J Biochem (Tokyo) 97:325, 1985

19. Coller BS, Cheresh DA, Asch E, Seligsohn U: Platelet vitronectin receptor expression differentiates Iraqi-Jewish from Arab patients with Glanzmann thrombasthenia in Israel. Blood 77:75, 1991

20. Loscalzo J, Inbal A, Handin RI: von Willebrand protein facilitates platelet incorporation into polymerizing fibrin. J Clin Invest 78:1112, 1986

21. Shattil SJ, Gao J, Kashiwagi H: Not just another pretty face: 
Regulation of platelet function at the cytoplasmic face of integrin alpha IIb beta 3. Thromb Haemost 78:220, 1997

22. Plow EF, McEver RP, Coller BS, Marguerie GA, Ginsburg MH: Related binding mechanisms for fibrinogen, fibronectin, von Willebrand factor and thrombospondin on thrombin-stimulated human platelets. Blood 66:724, 1985

23. Tuszynski GP, Kornecki E, Cierniewski C, Knight LC, Koshy A, Srivastava S, Niewiarowski S, Walsh PN: Association of fibrin with the platelet cytoskeleton. J Biol Chem 259:5247, 1984

24. Hantgan RR: Fibrin protofibril and fibrinogen binding to ADPstimulated platelets: Evidence for a common mechanism. Biochim Biophys Acta 968:24, 1988

25. Cohen I, Gerrard JM, White JG: Ultrastructure of clots during isometric contraction. J Cell Biol 91:775, 1982

26. Hantgan RR, Hindriks G, Taylor RG, Sixma JJ, de Groot PG: Glycoprotein Ib, von Willebrand factor, and glycoprotein IIb:IIIa are all involved in platelet adhesion to fibrin in flowing whole blood. Blood $76: 345,1990$

27. Jen CJ, Hu SJ, Wu HJ, Lin TS, Mao CW: Platelet-fibrin interaction in the suspension and under flow conditions. Adv Exp Med Biol 281:277, 1990

28. Bithell TC, Parekh SJ, Strong RR: Platelet-function studies in the Bernard-Soulier syndrome. Ann N Y Acad Sci 201:145, 1972

29. Howard MA, Hutton RA, Hardisty RM: Hereditary giant platelet syndrome: A disorder of a new aspect of platelet function. BMJ 2:586, 1973

30. Weiss HJ, Tschopp TB, Baumgartner HR, Sussman II, Johnson MM, Egan JJ: Decreased adhesion of giant (Bernard-Soulier) platelets to subendothelium. Further implications on the role of the von Willebrand factor in hemostasis. Am J Med 57:920, 1974

31. Walsh PN, Mills DC, Pareti FI, Stewart GJ, MacFarlane DE, Johnson MM, Egan JJ: Hereditary giant platelet syndrome. Absence of collagen-induced coagulant activity and deficiency of factor-XI binding to platelets. Br J Haematol 29:639, 1975

32. Caen J, Bellucci S: The defective prothrombin consumption in Bernard-Soulier syndrome. Hypotheses from 1948 to 1982. Blood Cells 9:389, 1983

33. Blomback B: Fibrinogen and fibrin-proteins with complex roles in hemostasis and thrombosis. Thromb Res 83:1, 1996

34. Warkentin TE, Hayward CP, Boshkov LK, Santos AV, Sheppard JA, Bode AP, Kelton JG: Sera from patients with heparin-induced thrombocytopenia generate platelet-derived microparticles with procoagulant activity: An explanation for the thrombotic complications of heparin-induced thrombocytopenia. Blood 84:3691, 1994

35. Lee DH, Warkentin TE, Denomme GA, Hayward CP, Kelton JG: A diagnostic test for heparin-induced thrombocytopenia: Detection of platelet microparticles using flow cytometry. Br J Haematol 95:724, 1996

36. Barry OP, Pratico D, Lawson JA, FitzGerald GA: Transcellular activation of platelets and endothelial cells by bioactive lipids in platelet microparticles. J Clin Invest 99:2118, 1997

37. Barry OP, Pratico D, Savani RC, FitzGerald GA: Modulation of monocyte-endothelial cell interactions by platelet microparticles. J Clin Invest 102:136, 1998

38. Thompson SG, Kienast J, Pyke SD, Haverkate F, van de Loo JC: Hemostatic factors and the risk of myocardial infarction or sudden death in patients with angina pectoris. N Engl J Med 332:635, 1995

39. Jansson JH, Nilsson TK, Johnson O: von Willebrand factor in plasma: A novel risk factor for recurrent myocardial infarction and death. Br Heart J 66:351, 1991

40. Catto AJ, Carter AM, Barrett JH, Bamford J, Rice PJ, Grant PJ: von Willebrand factor and factor VIII:C in acute cerebrovascular disease. Relationship to stroke subtype and mortality. Thromb Haemost 77:1104, 1997 